\section{AIDS threatens Asia}

\section{Florence}

NEw data reported last week by experts a1 the 7th International AIDS Conference in Florence indicated that developing countries are now facing an even worse AIDS emergency than previously believed.

The latest epidemiological studies performed by the World Health Organization (WHO) show that even though the incidence of AIDS is still low and is just beginning to be reported in many developing countries such as India, the disease is beginning to spread at an alarming speed. Although earlier data had shown Africa to be seriously endangered by the spread of HIV, the virus that causes AIDS, the new data reveal an alarming rate of increase in both Asia and Latin America as well.

By 2000, more than 90 per cent of HIV infections in the world will probably be found in the developing world, reports James Chin, a WHO epidemiologist in Geneva. At the same time, the number of new infections in industrialized countries will begin to level off or even to decline because of changes in behaviour.

The new data show that HIV has spread in India far beyond its initial entry points of the port cities of Madras and Bombay and is beginning to threaten rural populations, which are virtually defenceless against the virus because of a lack of information and condoms. One Indian official, Vulimiri Ramalingaswami of the All India Institute of Medical Sciences in New Delhi, said that India is "sitting on top of a volcano".

In Thailand, HIV has begun to race through the population with a remarkable speed, says Chin. The prime minister of Thailand recently told WHO that the estimated number of people infected with HIV increased from 200,000 to 400,000 in just the six months between June and December 1990. The prevalence of HIV among male military recruits had jumped from two per cent to six per cent during the same period.

Accordingly, WHO raised its estimate for the present number of HIV infections in South Asia from 500,000 to $1,000,000$, Chin said. While he stressed a basic uncertainty about the figures (which other epidemiologists said could be off by as much as 95 per cent), he also said that it is more likely that the WHO estimates will be revised upward rather than downward as more data become available.

At the same time, there is little money available in many developing countries to combat AIDS. In Uganda, for example, President Yoweri Kaguta Museveni said that per capita health spending amounts to just $\$ 3.50$ a year - not nearly enough to treat people with AIDS, let alone try to prevent infection.

By 2000 , about 90 per cent of the transmissions of the virus are expected to occur through heterosexual intercourse, despite the fact that this is one of the least efficient methods of transmission. Therefore, William Haseltine of Harvard University said it is time that AIDS, originally thought of as primarily a homosexual disease, should be recognized as being a "lethal venereal disease" that can be transmitted from fully healthy men to fully healthy women through mucous membranes.

- Meanwhile, the dispute over who discovered the AIDS virus flared up anew, despite unprecedented calls from activists asking the principals to stop wasting their time on the matter.

Luc Montagnier of the Pasteur Institute, officially recognized as the co-discoverer of the virus and its role in causing AIDS, along with Robert Gallo of the US National Institutes of Health, told Nature that "France deserves a gesture from NIH and our American colleagues" to make up for time and money wasted by the dispute "because of the early fault of Dr Gallo. There should be some reparations" to make up for that, he said.

Montagnier and the director of Institut Pasteur, Maxime Schwartz, denied that Institut Pasteur is interested in re-opening the arguments over the royalties from an AIDS blood test developed in Gallo's laboratory royalties which have been split 50-50 since an agreement in 1987 between NIH, Institut Pasteur and the two governments involved.

But Schwartz hinted that if Institut Pasteur is displeased with the result of a current NIH inquiry into the Gallo laboratory's handling of the case, then the Institut Pasteur might choose to do something about it. "This is not over yet," he said.

Meanwhile, Project Inform, an AIDS activist group based in San Francisco, urged an end to what it called a "harassment and misinformation campaign" against Gallo. It called on Gallo, Montagnier, Chicago Tribune journalist John Crewdson and others in any way involved in the dispute over the origin of the virus to "end this ludicrous debate".

Steven Dickman

\title{
Researchers bow to activist pressure
}

UNDER heavy pressure from US activists, the chairman of next year's international AIDS conference last week reversed his position and announced that the conference will not be held in Boston in 1992 unless the United States drops its restrictions on the entry of both travellers and immigrants who carry HIV, the virus that causes AIDS.

Max Essex of Harvard University said he changed his position after receiving "ultimatums" from activists who threatened to disrupt the conference if it were held. Activists were reported to have said that "blood would run in the streets" of Boston if the meeting were held.

If the meeting is not held in Boston, however, chances are that it will not be held at all. The intemational AIDS Society, which has been the official sponsor for each of the first seven international AIDS conferences, announced here that if the conference could not be held in Boston, the society would not sanction any other site. The next conference after that is scheduled to be held in Berlin in 1993.
For the meeting to be held in the United States, the US government would have to reverse its position again on the issue of travel and immigration restrictions - an occurrence that US government researchers like Anthony Fauci of the National Institutes of Health considered "almost

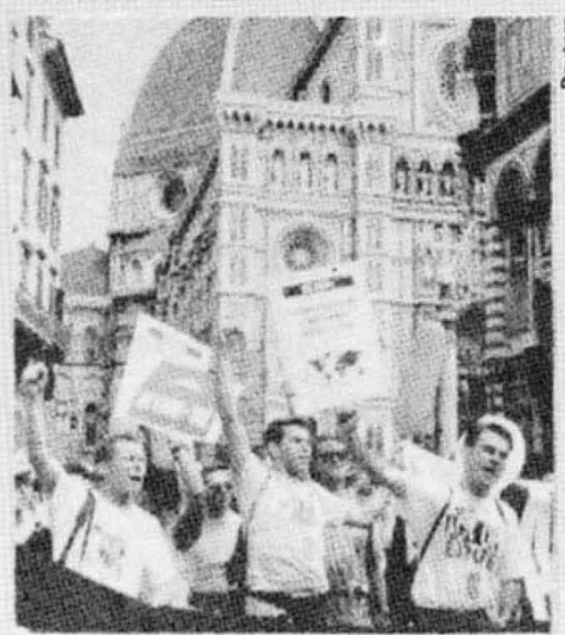

Demonstrating against discrimination. inconceivable". Essex said that unless all US travel and immigration restrictions against HIV-infected people are lifted by 3 August, "there will be no conference in Boston".

At this early stage, it is hard to predict the consequences of Essex's switching his position under pressure. But Meinrad Koch of Germany, executive secretary of the International AIDS Society and a coorganizer of the 1993 Berlin meeting, criticised Essex for "going overboard" in demanding that the immigration restrictions be reversed. "He was playing to a vocal minority," said Koch.

Koch sees two possible outcomes from Essex's decision, which he characterizes as a case of science bowing before irrationality. Either "scientists will become prisoners of the activists," he said, or there will be increasing hostility among scientists toward the activist groups. Either way, it will contribute to making the Berlin meeting a difficult task in a city which is the home of the largest gay community in Germany.

Steven Dickman 